\title{
Household-level Social Capital in Cameroon and Children's Schooling: A Gender Analysis
}

\author{
Johannes Tabi Atemnkeng*
}

\begin{abstract}
This article examines household-level social capital as a determinant of children's schooling using a cross-sectional data of the 2001 Cameroon Household Survey. Reduced form demand equations of schooling for the entire sample, male and female children are estimated separately. Results indicate that parent's education and income strongly influence parental decisions towards a child's schooling. However, social capital, especially in the female dimension, is more important as both male and female children are equally given the opportunity to attend school and there is no gender bias in children's schooling outcome when parents participate in groups or associations. We recommend the building of social capital by creating associations and encouraging females to be actively involved in such associative groups.
\end{abstract}

\section{Résumé}

Cet article utilise les données diversifiées du recensement des familles au Cameroun en 2001, pour faire une analyse du capital social au niveau familial en tant que facteur déterminant dans l'éducation des enfants. Les résultats de l'étude indiquent que le niveau d'éducation des parents ainsi que leurs moyens financiers influencent les décisions liées à l'éducation de leurs enfants. Cependant, le capital social, en particulier dans le cas de la fille, est plus important car garçons et filles ont les mêmes chances d'avoir accès à l'éducation et d'avoir de bons résultats à l'école quand les parents sont membres de groupes ou d'associations. Dés lors, nous recommandons le renforcement du capital social à travers la création d'associations qui encouragent les femmes à s'impliquer dans ces groupes associatifs.

* Faculty of Economics and Management, University of Dschang, Dschang, Cameroon.E-mail: jtabiatem@Yahoo.com 


\section{Introduction}

Education, which is a variant of human capital, generates substantial private and social benefits to households and thus the economy as a whole. Early work by economists in the field of human capital analysis recognized the importance of a variety of human attributes, including health, to the understanding of human capital, and not just skills and knowledge acquired through formal education or on-the-job experience (Becker 1993). The positive correlation, at the level of individuals, between completed formal education and subsequent lifetime earnings and employment is well documented (OECD 1998). Since the 2000 Dakar World Education Forum, there has been a worldwide resurgence in the recognition of the indispensable role goodquality basic education plays in a nation's economic and social development. This increased awareness is particularly evident in Sub-Saharan Africa (SSA), which is the region furthest from reaching the goal of basic Education for All (Birger 2002). Most African countries have devoted considerable attention to educating the generations of people born since the independence era. Their efforts reflect the political will expressed by the Charter on Education adopted at the 1961 Conference of Addis Ababa and the 1990 Jomtien World Declaration on Education for All, and subsequently reaffirmed in the 2000 Dakar Framework for Action. Despite their efforts, African governments continue to face rising illiteracy, grade-repetition and drop-out rates, as well as growing numbers of expulsions, especially among girls.

The level of schooling attainment continues to be low in Sub-Saharan African countries, including Cameroon, which recorded a population of about 15.7 million people in 2001, with a schooling population of over 7 million children. The net primary school enrolment rate for girls is 71 per cent, compared to 76 per cent for boys. Regional disparities also exist within the country and girls' national drop-out rates are so high that the net enrolment figure for secondary school is a mere 20 per cent (UNICEF 2003).

It is said that the main issues affecting girls' schooling outcomes, especially access to schooling relative to boys include, among others: low parental incomes and education, ability to use children's labour, non-availability or high cost of schooling, low returns to schooling for females relative to men, and the influence of cultural and social factors (see Alderman and King 1998 for details). The relationships between community participation and access to and quality of education in Sub-Saharan Africa are well documented (see ERNWACA 2002; N'Jie et al. 2002; Koura 2001).

What is quite often neglected, and sadly so, in discussions and policies aimed at greater equality of educational opportunities for males and females, is variables of group participation within the families or households. To increase gender equity in access to schooling requires, among other things, 
paying attention to available social capital in the home. The returns on investment in the education of females have been found to be much higher (Alayande et al 2000; Tawah 1998). Therefore it is worthwhile examining the effect of social capital on the persistence of male/female disparities in access to schooling. This would help to reverse the existing drop-out rates, which appear higher for females than male students, as observed in Table 2. Though public investment in education may be gender-neutral, parental decisions to invest in children's education are always gender-biased in favour of boys (see the literature on gender differences in schooling outcomes, e.g. Gertler and Alderman 1989; Zhang and Davies 1995; Kingdon 1998; Dollar and Gatti 1999; Olanrewaju 2003). Gender inequality in schooling may hinder the socio-economic development of a country if one has to recall the multiple roles of women, viz. health agent, educator, mother, farmer in most families in Sub-Saharan Africa.

In this article, we consider household-level social capital as an important factor in addressing gender bias in education. Our empirical analysis simultaneously examines three different schooling outcomes: 'never enrolled', 'dropped out' and 'currently enrolled' in school. This distinction helps in the analysis of conditions under which a child is likely to have had some schooling rather than none. This is important because using only 'currently enrolled' as the response variable, we are likely to lose valuable information on those children who may have dropped out of school after gaining basic literacy and numeracy skills (Dancer and Rammohan 2007).

In the empirical estimation, we use a multinomial logit model. With 'never enrolled in school' as our base, we jointly estimate the probability of 'dropping-out of school' and being 'currently enrolled'. The estimation is done for the entire sample including separate models for male and female.

The rest of the article is organised as follows: the second section discusses the issues on social capital and education, while in section three we introduce the data and summary statistics on the variables used in our analysis, followed by the measure of social capital and our estimation strategy. The findings of our empirical estimates are presented in the last section, followed by the conclusions.

\section{Social Capital and Related Works: An Overview}

Social capital refers to the quality of human relationships and the opportunities that emanate from them that could be of benefit to the population concerned.

Education, which is a variant of human capital, includes the skills and knowledge we gather in formal and informal learning whereas social capital is an asset built from meaningful interactions between people. The later facilitates the learning and use of skills and knowledge and could be a powerful 
force to influence parental decisions to send their children to school. Although social capital has been popularized only recently, following Bourdieu's (1980 1986), Coleman's (1988 1990) and Putnam’s (1993 1995) prominent studies, the concept of social capital has a long intellectual history in the social sciences. The sense in which the term is used today dates back over 90 years, when Hanifan (1916) invoked the concept of social capital to explain the importance of community participation in enhancing school performance. After Hanifan's work, the idea of social capital disappeared and was reinvented by a team of Canadian urban sociologists (Seely; Sim and Loosely 1956), within a research on urban communities' culture, by Homans (1961) for a theory of social interactions, and by Loury (1977) for a study on income distribution.

The World Bank refers to social capital as the institutions, relationships and norms that shape the quality and quantity of a society's social interactions. Social capital is not just the sum of the institutions that underpin a society but more accurately the glue that holds them together (World Bank 1999). A narrow view of social capital regards it as a set of horizontal associations between people (Putnam 1993), consisting of social networks and associated norms that have an effect on the productivity and well-being of the community via a reduction in production costs.

The literature on the relationship between social capital and access and quality of schooling has been well documented in both developed and developing countries, including Sub-Saharan Africa. Both Putnam (2000) and Halpern (1999) identified that education influences the creation of social capital while this in turn favours educational achievements. Meier (1999) also suggests that social relationships and the assistance provided through them have a positive impact on academic achievement among adolescents. Evidence of correlation also exists between participation in associative groups and schooling enrolment (Smith et al. 1995; Teachman et al. 1996).

This paper examines the impact of family social capital, and specifically the participation of male and female household members in associative groups, on the decision to enrol children in school. Family social capital has to do with the love and attention children receive from their parents, the security they feel and the encouragement they are given about the importance of education. There are a number of studies in African countries between family social capital or community participation in basic education and access and quality of education. Community participation here takes the form of purchase of supplies in schools, voluntary follow-up of students' work, financial contributions or commitments, etc.

N'jie et al. (2002) sought to highlight the tripartite relationship existing between Parent-Teacher Associations (PTAs), school management and school performance in Lower Basic Schools in Gambia. These authors derived 
a composite set of school and PTA variables that made a significant difference to school performance during 1997-2000, propose policy guidelines for the creation of a legal framework for developing effective school-PTA partnerships, and suggested perspectives for PTAs in the future of the Gambian educational system.

Koura (2001) reviewed a number of similar studies and identified the factors that influenced primary school abandonment as well as those that influenced girls to stay in school in 10 rural villages in the region of Segou in Mali. The author concluded that collaboration between the community and the school in rural Mali was essential in the fight to keep students in school, and girls in particular. Actions not based in community support would be in vain. Other studies on the positive link between community participation and access and quality of education include Sangare and Diarra (1997) and ERNWACA (2002). The latter provides a review of research results that appear to address the factors associated with access to schooling and the retention of students within the primary sector in Côte d'Ivoire and Gambia, including the relationships between community participation and access to and quality of education in Benin, Cameroon, Ghana, Mali and Togo.

In Cameroon, the best results in terms of access to and the quality of education have been achieved in communities that have the following characteristics: (i) a positive perception of basic education; (ii) regular and stable household incomes; (iii) a history of social mobilization through organized and dynamic structures; (iv) a form of educational involvement that goes beyond mere financial contributions; (v) the presence of external support mechanisms or of a development mechanism within the community; and (vi) the presence, within the community, of role models whose social status derives from their education.

In line with the same study, the connection between community participation and access to education, either in the formal or non-formal sectors, was confirmed by the result of the respondents. For example, all the teacher respondents who indicated that their communities cooperated with the school in its enrolment drive (51\%) also indicated that this cooperation resulted in improvements in the enrolments of the schools. Similarly, 56 per cent of facilitators confirmed that their enrolment drive was successful owing to community involvement in recruiting learners. However, they could not absorb all those who sought enrolment because of lack of space. In short, community participation in providing infrastructural facilities, organizing enrolment drives, motivating teachers and creating awareness of the benefits of education among community members generally leads to increased access and retention of pupils in school (ERNWACA 2002). 
The effect of social capital on children's schooling needs to be handled with care, as the former may be endogenous with child schooling. For example, does group membership contribute to higher child educational outcomes because the members are more exposed to information about the importance of school attendance, or do members who encourage their children's educational participation tend to be more socially active? Based on principal component analysis (PCA), ${ }^{1}$ Tabi (2010) constructed an aggregate social capital index (composed of density of membership, participation in decision-making and labour contribution) and found that household-level social capital excluding "social capital" of youngsters is not endogenous and determines children schooling or enrolment.

In this study, we use a multinomial regression which incorporates social capital in the home as an explanatory variable to determine jointly the probability of dropping out of school and of being currently enrolled.

\section{Background Issues, Data and Stylized Outcomes}

The data used for the purpose of this study are drawn from the Second Cameroon Household Survey (ECAM II) conducted across the ten provinces of Cameroon in 2001 by the National Institute of Statistics. ECAM II is a multipurpose household survey conducted in both urban and rural areas using a sample of 12,000 households of which 10,922 were actually visited. The survey was designed to measure socio-economic factors relevant to the standards of living. The survey includes information on household characteristics, household expenditures on goods and services including health and education, etc. In the entire households, there were 425,921 individuals, comprising 49.1 per cent males and 50.9 per cent females. However, our analysis is limited to children aged 5 to 17 years, which practically corresponds to the primary and secondary school age range in Cameroon.

Table 1 provides the descriptive statistics and definition of the variables used in the study. These statistics together with the descriptive statistics for the different types of schooling outcomes in Tables 2 and 3 highlight the empirical results that are obtained in the econometric estimations. The enrolment rate of children, which is one of the primary variables of interest to this study, is given in the first five rows, presented according to gender and milieu of residence. The findings reveal that 87 per cent of children are currently enrolled in school with gender gap of 1 per cent. Of this total, 84 per cent are in rural areas while 89 per cent are enrolled in urban areas. 
Table 1: Descriptive Statistics of Variables for the Entire Sample

\begin{tabular}{|c|c|c|c|c|}
\hline Variable & Mini & Maxi & Mean & Std dev. \\
\hline $\begin{array}{l}\text { Enrolment }=1 \text { if a child is } \\
\text { currently enrolled in school }\end{array}$ & 0 & 1 & 0.8724 & 0.333 \\
\hline Girl child enrolment & 0 & 1 & 0.8663 & 0.340 \\
\hline Boy child enrolment & 0 & 1 & 0.8787 & 0.326 \\
\hline Urban enrolment & 0 & 1 & 0.8890 & 0.314 \\
\hline Rural enrolment & 0 & 1 & 0.8374 & 0.369 \\
\hline $\begin{array}{l}\text { Hsc Household-level } \\
\text { social capital }\end{array}$ & 0 & 1 & 0.237 & 0.294 \\
\hline $\begin{array}{l}\text { Hscml Male share of } \\
\text { social capital }\end{array}$ & 0 & 1 & 0.177 & 0.273 \\
\hline $\begin{array}{l}\text { Hscfe Female share of } \\
\text { social capital }\end{array}$ & 0 & 1 & 0.059 & 0.182 \\
\hline $\begin{array}{l}\text { Log income Household } \\
\text { per capita expenditure }\end{array}$ & 9.77 & 16.65 & 12.589 & 0.75166 \\
\hline Age of child years & 5 & 17 & 9.945 & 3.919 \\
\hline $\begin{array}{l}\text { Age2 The square of the age of } \\
\text { child expressed in years }\end{array}$ & 25 & 289 & 114.289 & 84.763 \\
\hline $\begin{array}{l}\text { Sexchild Gender of child = } 1 \text { if } \\
\text { female and } 0 \text { otherwise }\end{array}$ & 0 & 1 & 0.5184 & 0.499 \\
\hline $\begin{array}{l}\text { Headsex Gender of household } \\
\text { head }=1 \text { if female }\end{array}$ & 0 & 1 & 0.2439 & 0.429 \\
\hline Hhsize Size of the household & 1 & 38 & 5.13 & 3.519 \\
\hline $\begin{array}{l}\text { Under5 Number of persons in } \\
\text { household aged below } 5 \text { years }\end{array}$ & 0 & 9 & 0.71 & 0.962 \\
\hline $\begin{array}{l}\text { Adults Number of persons in } \\
\text { household aged } 19 \text { years and above }\end{array}$ & 1 & 19 & 2.442 & 1.480 \\
\hline $\begin{array}{l}\text { Milieu Place of residence }=1 \text { if } \\
\text { urban and } 0 \text { if rural }\end{array}$ & 0 & 1 & 0.6470 & 0.4779 \\
\hline $\begin{array}{l}\text { Fathned Father has no formal } \\
\text { education }\end{array}$ & 0 & 1 & 0.1336 & 0.3401 \\
\hline
\end{tabular}


Table 1: Continued

\begin{tabular}{lcccc}
\hline Variable & Mini & Maxi & Mean & Std dev \\
\hline $\begin{array}{l}\text { Fathpry Father has primary } \\
\text { education }\end{array}$ & 0 & 1 & 0.1770 & 0.3816 \\
$\begin{array}{l}\text { Fathppry Father has } \\
\text { post-primary education }\end{array}$ & 0 & 1 & 0.1766 & 0.3813 \\
$\begin{array}{l}\text { Fathned Father has } \\
\text { post-secondary education }\end{array}$ & 0 & 1 & 0.0445 & 0.2061 \\
$\begin{array}{l}\text { Mothned Mother has no } \\
\text { formal education }\end{array}$ & 0 & 1 & 0.1996 & 0.3997 \\
$\begin{array}{l}\text { Mothpry Mother has primary } \\
\text { education }\end{array}$ & 0 & 1 & 0.2598 & 0.4385 \\
$\begin{array}{l}\text { Mothppry Mother has } \\
\text { post-primary education }\end{array}$ & 0 & 1 & 0.2380 & 0.4258 \\
$\begin{array}{l}\text { Mothpsc Mother has } \\
\text { post-secondary education }\end{array}$ & 0 & 1 & 0.0199 & 0.1396 \\
\hline
\end{tabular}

Source: Computed from Cameroon Household Survey (ECAM2).

In Table 2, we present the schooling outcomes of children by age and by gender. As in Olanrewaju (2003), the highest figures for both male and female enrolment rate occur at 11 years old whereas at 17 years of age, enrolment rate is least coupled with the highest withdrawal rates from school. For the primary school, the average enrolment rate for children is 74 per cent for males and 70 per cent for females, giving a gender schooling gap of 4 per cent. 
Table 2: An Overview of Children's Schooling Outcomes in Cameroon by Sex and Age of Child

\begin{tabular}{ccccccc} 
& \multicolumn{5}{c}{ Male } & \multicolumn{3}{c}{ Female } \\
\cline { 2 - 7 } Age in & Illiteracy & Enrolment & Withdrawal & Illiteracy & Enrolment & Withdrawal \\
years & Rate & Rate & Rate & Rate & Rate & Rate \\
\hline 5 & 50.2 & 39.0 & 10.8 & 53.2 & 35.2 & 11.6 \\
6 & 34.3 & 57.3 & 8.4 & 35.7 & 55.9 & 8.4 \\
7 & 21.5 & 73.2 & 5.3 & 25.9 & 68.1 & 6.0 \\
8 & 14.7 & 80.7 & 4.6 & 18.6 & 78.7 & 2.7 \\
9 & 9.8 & 87.8 & 2.4 & 16.6 & 81.6 & 1.8 \\
10 & 11.0 & 87.3 & 1.6 & 14.8 & 83.2 & 2.1 \\
11 & 4.9 & 93.8 & 1.3 & 12.0 & 84.8 & 3.2 \\
Average & & & & & & \\
Primary School & & & & & \\
Age & 20.91 & 74.15 & 4.9 & 25.25 & 69.64 & 5.11 \\
12 & 7.8 & 88.1 & 4.1 & 17.0 & 80.4 & 2.6 \\
13 & 7.7 & 85.8 & 6.5 & 12.3 & 81.8 & 5.9 \\
14 & 5.9 & 85.0 & 9.1 & 11.7 & 76.6 & 11.7 \\
15 & 8.2 & 76.4 & 15.4 & 21.4 & 62.0 & 16.9 \\
16 & 8.8 & 73.2 & 18.0 & 14.3 & 59.1 & 26.5 \\
17 & 8.3 & 61.7 & 30.0 & 20.7 & 43.1 & 36.2 \\
Average & Secondary & & & & & \\
School Age & 7.78 & 78.36 & 13.85 & 16.18 & 67.16 & 16.63 \\
Total & $\mathbf{1 5 . 5}$ & $\mathbf{7 6 . 1}$ & $\mathbf{8 . 4}$ & $\mathbf{2 1 . 1 6}$ & $\mathbf{6 8 . 6 0}$ & $\mathbf{9 . 7}$ \\
\hline & & & & & & \\
\hline
\end{tabular}

Source: Computed by Author from the 2001 Cameroon Household Survey (ECAM 2).

Notes:

1. Illiteracy rate is computed as the proportion of children who have never been to school.

2. Enrolment rate is the proportion of children who were enrolled and attended in school in 2001.

3. Withdrawal rate is calculated as the proportion of children who were in school before but dropped out of school in 2001.

The average enrolment for children of secondary school age is 78 and 69 per cent for males and females respectively, which indicates a gender gap of 9 per cent. Generally, the enrolment rate for all children at both the primary and secondary school levels is about 76 per cent for males and 69 per cent for females, representing a gap of 7 per cent.These gender gaps in 
children schooling outcomes could be explained by the explanatory variables used in the econometric models of which the descriptive statistics are detailed in Table 3.

We control for household and child characteristics by including variables relating to household income, the presence of adults and pre-school age siblings, household head and their spouse's level of education, gender of household head, and family social capital and its gender character. Child characteristics include the sex and age of child (Table 3).

There appears to be an intergenerational transmission of schooling levels, with a positive correlation between children's schooling outcomes and parental levels of education. For example, children that are currently enrolled in school typically belong to households where both father and mother's education level are high. For instance, children who never went to school are in households where the highest proportions of fathers (0.391) and mothers (0.50) have no level of education. However, when the level of education of parents is high (observed in terms of proportion who went to school), as in the case of post-primary ( 0.16 for fathers and 0.22 for mothers) and post-secondary education ( 0.03 for fathers and 0.02 for mothers), more children enrolled relative to never enrolled or dropped out of school.

We observe similar trends for the effect of the sex of household head on children's schooling outcomes, where currently enrolled children belong to households headed mostly by females $(0.26)$. This contrasts with households where the children have either dropped out of school (0.22) or have never attended school (0.14). Further, more of the children in urban households, especially older ones and being male, were in school relative to those that never enrolled or dropped out of school.

Interestingly, children that are currently enrolled belong to smaller households (6.4) relative to children that 'drop out' of school or who have 'never attended' school.

These results, together with the fact that the lowest proportion of children that report 'never enrolled in school' lived in households where there were no pre-school age siblings, suggests a 'quantity-quality trade-off' in schooling investment (Becker and Lewis 1973; Dancer and Rammohan 2007). ${ }^{2}$ We also observe that the highest proportion of children who never attended school lived in the poorest households, with a per capita expenditure in logform of 5.19 below rich households. Finally, households who participate in groups or belong to an association (with a higher social capital of 0.215 ) have more children enrolled relative to drop-outs (with social capital of $0.196)$ or never went to school (0.114). 
Table 3: Descriptive Statistics for the Different Types of Schooling Outcomes per cent

\begin{tabular}{llll}
\hline Child & $\begin{array}{l}\text { Never } \\
\text { attended }\end{array}$ & $\begin{array}{l}\text { Dropped out } \\
\text { of School }\end{array}$ & $\begin{array}{l}\text { Currently } \\
\text { in School }\end{array}$ \\
\cline { 2 - 4 } characteristics & & & \\
\hline Age & $8.01(3.80)$ & $11.05(4.904)$ & $9.38(3.52)$ \\
Sex & $0.594(0.491)$ & $0.539(0.499)$ & $0.492(0.499)$ \\
Household & & & \\
characteristics & & & \\
Headsex & $0.137(0.344)$ & $0.222(0.416)$ & $0.260(0.438)$ \\
Hhsize & $6.96(3.62)$ & $6.53(3.37)$ & $6.43(3.24)$ \\
Under5 & $1.17(1.09)$ & $0.93(1.05)$ & $0.89(1.01)$ \\
Adults & $2.63(1.42)$ & $2.59(1.55)$ & $2.71(1.52)$ \\
Milieu & $0.191(0.414)$ & $0.355(0.478)$ & $0.459(0.498)$ \\
Fathned & $0.390(0.487)$ & $0.189(0.391)$ & $0.115(0.319)$ \\
Fathpry & $0.195(0.396)$ & $0.215(0.411)$ & $0.191(0.393)$ \\
Fathppry & $0.072(0.259)$ & $0.127(0.333)$ & $0.158(0.364)$ \\
Fathpsc & $0.005(0.074)$ & $0.018(0.136)$ & $0.033(0.181)$ \\
Mothned & $0.501(0.5)$ & $0.253(0.434)$ & $0.179(0.383)$ \\
Mothpry & $0.210(0.407)$ & $0.302(0.459)$ & $0.285(0.451)$ \\
Mothppry & $0.053(0.224)$ & $0.145(0.352)$ & $0.217(0.412)$ \\
Mothpsc & $0.0009(0.029)$ & $0.007(0.084)$ & $0.016(0.127)$ \\
Hsc & $0.114(0.175)$ & $0.196(0.241)$ & $0.215(0.231)$ \\
Hscfe & $0.019(0.091)$ & $0.046(0.141)$ & $0.054(0.147)$ \\
Hscml & $0.095(0.161)$ & $0.15(0.228)$ & $0.161(0.221)$ \\
Log income & $5.19(0.256)$ & $5.29(0.271)$ & $5.34(0.299)$ \\
\hline
\end{tabular}

Source: Computed by Author from the 2001 Cameroon Household Survey (ECAM 2).

Note: Standard deviations are in parentheses. 
Table 4: Reasons for Withdrawal from School

\begin{tabular}{lccc}
\hline Reason & Male & Female & Average \\
\hline Expense & 0.193 & 0.18 & 0.185 \\
Employment/ & & & \\
Apprenticeship & 0.037 & 0.019 & 0.028 \\
Failed out & 0.056 & 0.059 & 0.059 \\
Health problem & 0.043 & 0.034 & 0.039 \\
Marriage/Pregnancy & 0.00 & 0.033 & 0.017 \\
Distance & 0.065 & 0.066 & 0.066 \\
Below age & 0.297 & 0.258 & 0.278 \\
Others & 0.308 & 0.351 & 0.330
\end{tabular}

Source: Computed by Author from the 2001 Cameroon Household Survey (ECAM 2).

Table 4 shows some 3.3 per cent of girls withdrew from school for marriage reasons or pregnancy and 3.7 per cent of boys for employment or apprenticeship purposes. Further, most children withdrew for other reasons not specified (females about 35\% and males about 31\%). Lastly, financial constraints and health problems accounted for the withdrawal of relatively more males than females. In this paper, we find social capital at the household level to be a possible factor that could generate a gender balance in parental decisions towards the schooling of their children.

\section{Measure of Social Capital}

The effectiveness with which social capital, in the form of local associations, can fulfil its role in disseminating information, reducing opportunistic behaviour and facilitating collective decision-making depends on many aspects of the association, reflecting its structure, membership and functioning. The major problem surrounding studies that relates social capital to development is the measurement of social capital. Social capital has been measured in a variety of innovative ways, and as Woolcock and Narayan (2000) observe, obtaining a single 'true' measure is probably not possible, or perhaps even desirable for a number of reasons. One of the main reasons is that the most comprehensive definitions of social capital are multidimensional, incorporating different levels and units of analysis. 
Grootaert et al. (2004) and Grootaert (1999) provide a set of empirical tools for measuring social capital as a means of restoring dialogue and agreement in theoretical and empirical debates. They identify six dimensions of social capital, as follows: groups and networks; trust and solidarity; collective action and cooperation; information and communication; social cohesion and inclusion; empowerment and political action. ${ }^{3}$

In this article, we adopt density of membership, which is probably the most used and recognized proxy in the literature of social capital. Nevertheless, in Tabi (2010) measures such as density of membership, participation in decision-making and labour contribution are found to be highly correlated and so, any of them have the same effect on various household's outcomes. For this reason using density of membership as the social capital measure is acceptable here. It is measured by the number of memberships of each household in existing associations. The total number of active memberships in each community is added up across households and normalized by household size (Grootaert et al. 2004).

\section{Econometric Technique}

In the analysis we considered three variables relating to schooling outcomes: never attended school, dropped out of school and currently in school. The dependent variable is the discrete variable, $\mathrm{CHDSCH}$, determined from selfreported answers to the question on whether or not the child is enrolled in school. This variable equals 0 if the child has never attended school; 1 , if the child has dropped out of school; and 2, if the child is currently enrolled in school.

A multivariate logistic regression technique is used to estimate a reducedform demand equation for schooling outcomes. This involves a regression of the models for the entire sample, male and female children. The variable of interest among the household characteristics is the household level or family social capital. Since the issue of gender in child schooling is important in the study, we also incorporate other household-specific gender variables such as female headship, the level of schooling of the household head's spouse and the gender aspect of social capital.

The model operates by assuming that each child has an unobserved utility associated with each of the discrete outcomes. The utility index is assumed to depend on personal and family characteristics. Individual children (or, more likely, their families) then choose the alternative with the highest utility. Utility is not observable and so cannot be estimated. With a linear random utility model, the function takes the following form:

$U_{i j}=\alpha^{\prime}{ }_{j} X_{i}+\varepsilon_{i j} ; j=0,1,2$. Under the assumption that $\left(\varepsilon_{i 0}-\varepsilon_{i j}\right)$ follows a logistic distribution, this random utility framework motivates the 
use of the multinomial logit model. Under this model specification, the probability that the $i^{\text {th }}$ child falls into the $j^{\text {th }}$ category is given by:

$$
P_{i j}=\frac{\exp \left(\alpha^{\prime}{ }_{j} x_{i}\right)}{\sum_{k=1}^{m} \exp \left(\alpha^{\prime}{ }_{k} x_{i}\right)}, \quad i=1, \cdots, n, \quad j=1, \cdots, m .
$$

If the $m^{\text {th }}$ category is taken to be the base category, then $a_{m}$ is normalized to zero. The vector of the á coefficients is got by the maximum likelihood method. Each coefficient shows the probability of a child to be considered as being currently in school or having dropped out with respect to a base category.

The econometric model is derived from the theory of household demand for schooling. It is assumed that parents will invest in the schooling of their children to the extent that the marginal benefits of schooling exceed the costs of the schooling investment. The outcome of this decision is determined by a set of individual and household characteristics. Thus:

$$
V_{i}=f\left(I_{i}, H_{i}, L\right)
$$

where $\mathrm{V}$ is the decision variable; never attended, dropped out of school or currently in school; $I$ is a vector of individual characteristics (such as age, age-squared, gender); $H$ is a vector of household and parental characteristics (such as the number of siblings below 5 years, number of persons above 19 years, gender of household head, level of education of parents, size of household, per capita household income and household-level social capital). The term $L$ refers to the geographical location, i.e. whether the household resides in a rural or urban area. These variables, which are described in Table 1, are introduced in the econometric model to examine their effects on schooling.

\section{Econometric Results}

The empirical results of the study are presented in Tables 5 to 7 . Table 5 reports the results for the entire sample, while Tables 6 and 7 contain the results for the male and female sample respectively. Each of the tables also provides estimation results on the link between social capital by gender and schooling.

The general results support the view that when household members (e.g. parents) actively participate in associative groups, it is more likely that both their boy and girl children (aged 5 to 17) will be currently enrolled or must have had some schooling relative to children who have never been to school. The effect is stronger for the case of the mother's membership in the association. The coefficient on the female share of social capital exceeds 
that of the male share (see Tables $5 b, 6 b$ and $7 b$ ). Similar effects have been determined in Mali by Koura (2001).

In order to further this analysis on the child's gender as an important determinant of schooling, three other variables, namely, sex of child, female headship and mother's level of education are incorporated in the model. The results prove that at the national level, relative to a female child who is never enrolled, a male child is more likely to be currently attending school and to have had some schooling than a female child (see Tables $5 \mathrm{a}$ and $5 \mathrm{~b}$ ). However, the probability of a female child to be currently enrolled rather than never being enrolled increases only in the urban areas (see Tables 7a and 7b).

Pertaining to female headship, a female child living in a female-headed household is more likely to be currently enrolled than never enrolled (see Table 7a). The effect is weaker for a male child living under a femaleheaded household, but the tendency is that such a male child is likely to have had some schooling rather than never (see Table 6a). These results are similar to the findings of Lioyd and Blanc (1996), which indicate that girls fare better in female headship in Sub-Saharan Africa.

Using the mother's level of education as a factor of schooling, we realized that as the level of education of mother increases from no education to post-secondary education, the probability for both girls and boys to be currently enrolled and to have had some schooling increases relative to no schooling.

We also find similar results as other studies (Lioyd and Blanc 1996; Glick and Sahn 2000; Olanrewaju 2003), in that household income proxied by per capita expenditure has a positive effect on schooling outcomes in any of the regressions.

The coefficients of age and age-squared (always positive and negative respectively) carry the right signs where significant. It is evident that as age of child increases the child is more likely to have attended school and enrolled rather than not to have been schooled before. However, the probability of having been enrolled or currently being enrolled increases at a decreasing rate with a child's age.

Looking at the influence of milieu of residence of children, our estimates show that children living in an urban milieu rather than rural areas are more likely to be currently enrolled relative to the base of 'never enrolled' in school. A large household experiences the tendency of reducing the likelihood of a child to be currently enrolled for the entire sample. The effect is reversed for both the male and female samples where increasing household size does not reduce the probability of schooling outcomes. It should be understood that the average household size in our sample is less than six persons and the income effect may dominate the size effect. 
As the number of pre-school age siblings increases, the probability of being current enrolled versus never enrolled significantly decreases for the male and female samples respectively, though it increases for the entire sample. Households with many older persons (i.e. above 19 years) have the tendency for their children to be currently enrolled relative to no enrolment for the entire sample. The older ones may be more helpful as far as the resources of the household are concerned. Lastly, as the level of education of the father increases from no education to some level of education, the likelihood for both male and female children to be currently enrolled and to have had some schooling increases.

\section{Conclusion and Policy Implications}

The determinants of children's schooling in Sub-Saharan Africa and other low-income countries have been widely studied. Using an econometric approach, this paper has attempted to incorporate social capital and its gender characteristic as an explanatory variable of schooling outcome. In the study, we used membership in associations to construct a proxy measure of social capital.

Using nationally representative data, we find that both male and female children are equally given the opportunity to attend school when parents participate in groups or associations. There is no gender bias in schooling when family or household social capital increases. With a higher level of household social capital, children are more likely to be attending and to have attended school, especially when this capital is generated from the female parent's participation in associations. Several other factors such as age, age-squared, sex of child, the number of siblings below 5 years, number of persons above 19 years, gender of household head, level of education of parents, size of household and per capita household income were also found to influence schooling outcomes.

How, then, does the evidence that household social capital provide greater opportunities for male and female children translate into policies that can make a difference?

Woolcock suggests that the policy response should not be a call for more choirs. Indeed, he emphasized that social capital is not a panacea, and more of it is not necessarily better (Woolcock 2001:15). However, social capital has a well-established relationship with the outcomes policy-makers are concerned with, such as economic growth, social inclusion, better health and well-being (Halpern 1999). The policy responses so far have focused on civic regeneration, volunteering and community self-help. The aim is to build social capital by strengthening local community networks. Based on the results of the study, policies that encourage the formation of associations, 
and more importantly those that encourage female participation, will increase gender equity in schooling for both male and female children.

Table 5a: Regression Results of Social Capital and Schooling: Entire Sample

\begin{tabular}{|c|c|c|c|c|}
\hline & \multicolumn{2}{|c|}{ Dropped out of School } & \multicolumn{2}{|c|}{ Currently in School } \\
\hline & Coefficient & P-value & Coefficient & P-value \\
\hline Constant & -5.13 & $0.00^{* * *}$ & -13.63 & $0.00^{* * *}$ \\
\hline Hsc & 1.84 & $0.00^{* * *}$ & 2.34 & $0.00^{* * *}$ \\
\hline Income & 0.146 & $0.08^{*}$ & 0.687 & $0.00^{* * *}$ \\
\hline Age & 0.260 & $0.02^{* *}$ & 1.16 & $0.00^{* * *}$ \\
\hline Age $^{2}$ & -0.001 & 0.84 & -0.048 & $0.00^{* * *}$ \\
\hline Milieu & 0.077 & 0.43 & 0.267 & $0.00^{* * *}$ \\
\hline Sex & -0.316 & $0.01^{* *}$ & -0.658 & $0.00^{* * *}$ \\
\hline Headsex & 0.558 & $0.00^{* * *}$ & 0.466 & $0.00^{* * *}$ \\
\hline Hhsize & -0.008 & 0.75 & -0.244 & $0.00^{* * *}$ \\
\hline Under 5 & -0.063 & 0.24 & 0.0879 & $0.06^{*}$ \\
\hline Adults & 0.008 & 0.85 & 0.356 & $0.00^{* * *}$ \\
\hline Fathned & -0.221 & 0.25 & -0.820 & $0.00^{* * *}$ \\
\hline Fathpry & 0.246 & 0.16 & 0.117 & 0.40 \\
\hline Fathppry & 0.553 & $0.00^{* * *}$ & 0.543 & $0.00^{* * *}$ \\
\hline Fathpsc & 0.526 & $0.09^{*}$ & 0.572 & $0.02^{* *}$ \\
\hline Mothned & -0.777 & $0.00^{* * *}$ & -0.834 & $0.00^{* * *}$ \\
\hline Mothpry & 0.499 & $0.00^{* * *}$ & 0.385 & $0.00^{* * *}$ \\
\hline Mothppry & 0.865 & $0.00^{* * *}$ & 1.14 & $0.00^{* * *}$ \\
\hline Mothpsc & 0.716 & 0.13 & 0.853 & $0.04^{* *}$ \\
\hline
\end{tabular}

Notes: $\quad *$ Indicates Significant at 10 per cent level;

** Indicates Significant at 5 per cent level; and

*** Indicates Significant at 1 per cent level. 
Table 5b: Regression Results of Social Capital by Gender and Schooling: Entire Sample

\begin{tabular}{lllll}
\hline & Coefficient & \multicolumn{3}{c}{ P-value } \\
\hline Constant & -5.10 & $0.00^{* * *}$ & -13.59 & $0.00^{* * *}$ \\
Hscfe & 2.82 & $0.00^{* * *}$ & 3.67 & $0.00^{* * *}$ \\
Hscml & 1.65 & $0.00^{* * *}$ & 2.03 & $0.00^{* * *}$ \\
Income & 0.144 & $0.09^{*}$ & 0.685 & $0.00^{* * *}$ \\
Age & 0.264 & $0.02^{* *}$ & 1.17 & $0.00^{* * *}$ \\
Age & -0.001 & 0.81 & -0.048 & $0.00^{* * *}$ \\
Milieu & 0.073 & 0.45 & 0.262 & $0.00^{* * *}$ \\
Sex & -0.318 & $0.01^{* *}$ & -0.659 & $0.00^{* * *}$ \\
Headsex & 0.441 & $0.03^{* *}$ & 0.262 & $0.09^{*}$ \\
Hhsize & -0.007 & 0.75 & -0.244 & $0.00^{* * *}$ \\
Under 5 & -0.064 & 0.24 & 0.087 & $0.06^{*}$ \\
Adults & 0.007 & 0.88 & 0.354 & $0.00^{* * *}$ \\
Fathned & -0.224 & 0.25 & -0.833 & $0.00^{* * *}$ \\
Fathpry & 0.250 & 0.16 & 0.119 & 0.39 \\
Fathppry & 0.558 & $0.00^{* * *}$ & 0.544 & $0.00^{* * *}$ \\
Fathpsc & 0.541 & $0.09^{*}$ & 0.586 & $0.02^{*}$ \\
Mothned & -0.776 & $0.00^{* * *}$ & -0.833 & $0.00^{* * *}$ \\
Mothpry & 0.501 & $0.00^{* * *}$ & 0.390 & $0.00^{* * *}$ \\
Mothppry & 0.868 & $0.00^{* * *}$ & 1.15 & $0.00^{* * *}$ \\
Mothpsc & 0.70 & 0.14 & 0.842 & $0.04^{* *}$ \\
\hline Note: & Int & & & \\
\hline
\end{tabular}

Notes: $\quad *$ Indicates Significant at 10 per cent level;

** Indicates Significant at 5 per cent level; and *** Indicates Significant at 1 per cent level. 
Table 6a: Regression Results of Social Capital and Schooling: Males

\begin{tabular}{|c|c|c|c|c|}
\hline \multicolumn{2}{|c|}{ Dropped out of School } & \multicolumn{3}{|c|}{ Currently in School } \\
\hline & Coefficient & P-value & Coefficient & P-value \\
\hline-5.13 & $0.00^{* * *}$ & -13.63 & $0.00^{* * *}$ & \\
\hline Constant & -0.984 & 0.66 & -11.7 & $0.00^{* * *}$ \\
\hline Hsc & 1.51 & $0.00^{* * *}$ & 2.39 & $0.00^{* * *}$ \\
\hline Income & -0.147 & 0.36 & 0.370 & $0.00^{* * *}$ \\
\hline Age & 0.153 & 0.46 & 1.52 & $0.00^{* * *}$ \\
\hline Age $^{2}$ & 0.001 & 0.85 & -0.065 & $0.00^{* * *}$ \\
\hline Milieu & 0.365 & $0.06^{*}$ & 0.203 & 0.15 \\
\hline Headsex & 0.559 & $0.10^{*}$ & 0.279 & 0.27 \\
\hline Hhsize & -0.035 & 0.55 & 0.164 & $0.00^{* * *}$ \\
\hline Under 5 & -0.081 & 0.47 & -0.207 & $0.00^{* * *}$ \\
\hline Adults & 0.132 & 0.18 & -0.026 & 0.72 \\
\hline Fathned & 0.011 & 0.98 & -0.813 & $0.00^{* * *}$ \\
\hline Fathpry & 0.474 & 0.19 & 0.251 & 0.33 \\
\hline Fathppry & 0.713 & $0.06^{*}$ & 0.341 & 0.23 \\
\hline Fathpsc & 0.597 & 0.55 & 1.41 & $0.07^{*}$ \\
\hline Mothned & -0.548 & $0.05^{* *}$ & -0.658 & $0.00^{* * *}$ \\
\hline Mothpry & 0.478 & $0.07^{*}$ & 0.554 & $0.00^{* * *}$ \\
\hline Mothppry & 0.837 & $0.01^{* *}$ & 1.45 & $0.00^{* * *}$ \\
\hline Mothpsc & -0.076 & 0.96 & 1.11 & .030 \\
\hline Notes: & $\begin{array}{cc}* & \text { Indicates } \\
* * & \text { Indicates } \\
* * & \text { Indicates S }\end{array}$ & $\begin{array}{l}\text { ant at } 1 \\
\text { ant at } 5 \\
\text { int at } 1\end{array}$ & $\begin{array}{l}\text { ent level; } \\
\text { nt level; and } \\
\text { t level. }\end{array}$ & \\
\hline
\end{tabular}


Table 6b: Regression Results of Social Capital by Gender and Schooling: Males Currently in School

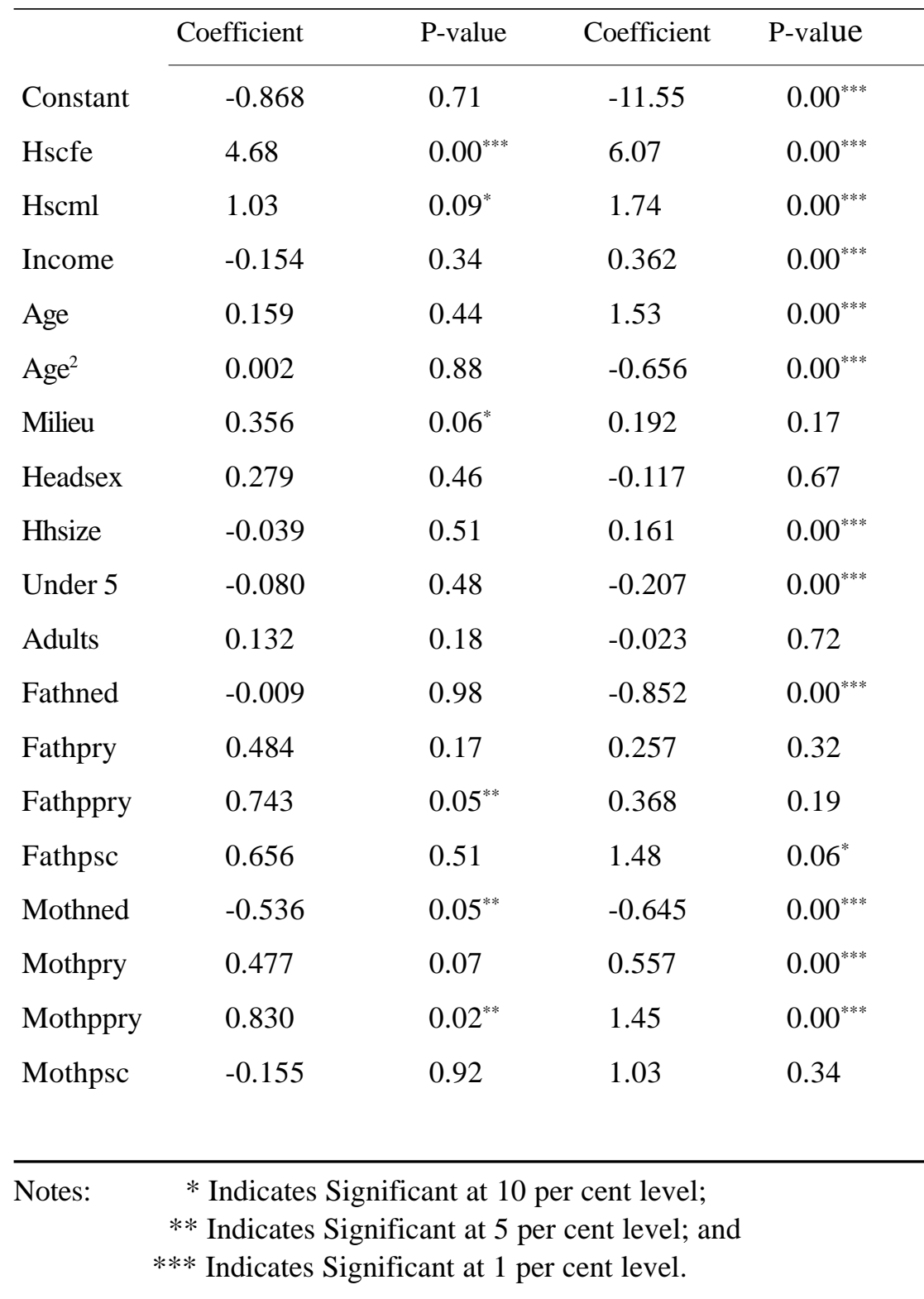


Table 7a: Regression Results of Social Capital by Gender and Schooling: Females

\begin{tabular}{|c|c|c|c|c|}
\hline & \multicolumn{2}{|c|}{ Dropped out of School } & \multicolumn{2}{|c|}{ Currently in School } \\
\hline & Coefficient & P-value & Coefficient & P-value \\
\hline Constant & -5.61 & $0.00^{* * *}$ & -14.65 & $0.00^{* * *}$ \\
\hline Hsc & 2.51 & $0.00^{* * *}$ & 2.80 & $0.00^{* * *}$ \\
\hline Income & 0.009 & $0.07^{*}$ & 0.529 & $0.00^{* * *}$ \\
\hline Age & 0.626 & $0.00^{* * *}$ & 1.61 & $0.00^{* * *}$ \\
\hline $\mathrm{Age}^{2}$ & -0.019 & $0.01^{* * *}$ & -0.071 & $0.00^{* * *}$ \\
\hline Milieu & 0.118 & 0.47 & 0.253 & $0.03^{* *}$ \\
\hline Headsex & 0.309 & 0.27 & 0.435 & $0.02^{* *}$ \\
\hline Hhsize & -0.028 & 0.57 & 0.168 & $0.00^{* * *}$ \\
\hline Under 5 & 0.026 & 0.79 & -0.331 & $0.00^{* * *}$ \\
\hline Adults & 0.019 & 0.83 & -0.029 & 0.61 \\
\hline Fathned & -0.269 & 0.38 & -0.722 & $0.00^{* * *}$ \\
\hline Fathpry & 0.399 & 0.17 & 0.331 & $0.09^{*}$ \\
\hline Fathppry & 0.705 & $0.03^{* *}$ & 0.848 & $0.00^{* * *}$ \\
\hline Fathpsc & -0.071 & 0.91 & 0.493 & 0.26 \\
\hline Mothned & -0.622 & $0.00^{* * *}$ & -0.829 & $0.00^{* * *}$ \\
\hline Mothpry & 0.695 & $0.00^{* * *}$ & 0.904 & $0.00^{* * *}$ \\
\hline Mothppry & 1.23 & $0.00^{* * *}$ & 1.75 & $0.00^{* * *}$ \\
\hline Mothpsc & 2.05 & $0.00^{* * *}$ & 1.71 & $0.03^{* *}$ \\
\hline
\end{tabular}

Notes: $\quad *$ Indicates Significant at 10 per cent level;

** Indicates Significant at 5 per cent level; and

*** Indicates Significant at 1 per cent level. 
Table 7b: Regression Results of Social Capital by Gender and Schooling: Females

\begin{tabular}{|c|c|c|c|c|}
\hline & \multicolumn{2}{|c|}{ Dropped out of School } & \multicolumn{2}{|c|}{ Currently in School } \\
\hline & Coefficient & P-value & Coefficient & P-value \\
\hline Constant & -5.61 & $0.00^{* * *}$ & -14.64 & $0.00^{* * *}$ \\
\hline Hscfe & 3.07 & $0.00^{* * *}$ & 3.49 & $0.00^{* * *}$ \\
\hline Hscml & 2.37 & $0.00^{* * *}$ & 2.61 & $0.00^{* * *}$ \\
\hline Income & 0.008 & $0.06^{*}$ & 0.528 & $0.00^{* * *}$ \\
\hline Age & 0.629 & $0.00^{* * *}$ & 1.61 & $0.00^{* * *}$ \\
\hline Age $^{2}$ & -0.019 & $0.01^{* *}$ & -0.072 & $0.00^{* * *}$ \\
\hline Milieu & 0.115 & 0.48 & 0.249 & $0.03^{* *}$ \\
\hline Headsex & 0.243 & 0.45 & 0.335 & 0.12 \\
\hline Hhsize & -0.028 & 0.56 & 0.169 & $0.00^{* * *}$ \\
\hline Under 5 & 0.025 & 0.79 & -0.331 & $0.00^{* * *}$ \\
\hline Adults & 0.018 & 0.83 & -0.029 & 0.60 \\
\hline Fathned & -0.271 & 0.38 & -0.729 & $0.00^{* * *}$ \\
\hline Fathpry & 0.401 & 0.17 & 0.331 & $0.10^{*}$ \\
\hline Fathppry & 0.707 & $0.03^{* *}$ & 0.848 & $0.00^{* * *}$ \\
\hline Fathpsc & -0.062 & $0.00^{* * *}$ & 0.502 & 0.25 \\
\hline Mothned & -0.622 & $0.00^{* * *}$ & -0.828 & $0.00^{* * *}$ \\
\hline Mothpry & 0.697 & $0.00^{* * *}$ & 0.908 & $0.00^{* * *}$ \\
\hline Mothppry & 1.24 & $0.00^{* * *}$ & 1.76 & $0.00^{* * *}$ \\
\hline Mothpsc & 2.04 & $0.02^{* *}$ & 1.70 & $0.03^{* *}$ \\
\hline otes: & $\begin{array}{l}\text { * Indicates } \\
\text { ** Indicates } \\
\text { ** Indicates }\end{array}$ & ant at 1 & $\begin{array}{l}\text { ent level; } \\
\text { nt level; and } \\
\text { at level. }\end{array}$ & \\
\hline
\end{tabular}




\section{Notes}

1. Principal or factor component is a linear combination of all variables. Either case is a multivariate statistical technique used to reduce the number of variables in a data set into a smaller number of 'dimensions'. In mathematical terms, from an initial set of n correlated variables, principal component analysis creates uncorrelated indices or components, where each component is a linear weighted combination of the initial variables. For example, from a set of variables $\mathrm{X} 1$ through to $\mathrm{n}$ :

$$
\begin{aligned}
& P C_{1}=a_{11} X_{1}+a_{12} X_{2}+\ldots .+a_{1 n} X_{n} \\
& P C_{m}=a_{m 1} X_{1}+a_{m 2} X_{2}+\ldots .+a_{m n} X_{n}
\end{aligned}
$$

The weights for each principal component are given by the eigenvectors of the correlation matrix, or if the original data were standardized, the co-variance matrix. The components are ordered so that the first component (PC1) explains the largest possible amount of variation in the original data, subject to the constraint that the sum of the squared weights (a $211+a 212+\ldots .+a 21 n$ ) is equal to one (Tabi 2010).

2. Households with more children under 5 years of age (1.17) never attended school relative to those that enrolled in households with less pre-school age siblings (0.89).

3. Grootaert also includes measures of democratic participation, meeting attendance, decision-making and fees as indices of social capital. Furthermore, some studies, e.g. Knack and Keefer (1997), La Porta et al. (1992) and Alesina and La Ferrara (2000), Narayan and Pritchett (1999), Grootaert (1999) and Maluccio et al. (2002), have used measures like density of membership or trust indices.

\section{References}

Adelman, I. and Morris, C.T., 1967, Society, Politics and Economic Development: A quantitative approach, Baltimore: Johns Hopkins University Press.

Alderman, H. and King, E.M., 1998, Gender Differences in Parental Investment in Education, Structural Change and Economic Dynamics 9, 453-468.

Alesina, A. and La Ferrara, E., 1999, Participation in Heterogeneous Communities, NBER Working Paper No. 7444 (December).

Becker, G., 1993, Human Capital: A Theoretical and Empirical Analysis, with Special Reference to Education, 3rdedn, Chicago: University of Chicago Press.

Bourdieu, P., 1980, Le capital social, Actes de la Recherche en Sciences Sociales 31(2-3).

Bourdieu, P., 1986, The Forms of Capital, in Richardson, J.G. (ed.), Handbook of Theory and Research for the Sociology of Education, New York: Greenwood Press, pp. 241-258. 
Birger, Fredriksen, 2002, Education for All African Children by 2015: What Will It Take to Keep the Promise?, Paper prepared for the Forum on Cost and Financing of Education in Nigeria, 18-19 September.

Coleman, J., 1988, Social Capital in the Creation of Human Capital, American Journal of Sociology 94 (Supplement).

Coleman, J.,1990, Foundations of Social Theory, Cambridge, MA, Harvard University Press.

Dancer, D. and Rammohan, A., 2007, The Determinants of Schooling in Egypt: The Role of Gender and Rural Urban Residence, Oxford Development Studies, 2007, Vol. 35, Issue 2.

Dee, Thomas S., 2003, Are There Civic Returns to Education?, NBER Paper No. 9588.

Dollar, D. and Gatti, R., 1999, Gender Inequality, Income and Growth: Are Good times Good for Women?, Working Paper Series, No. 1, Washington, DC: World Bank.

Dreze, J. and Kingdon, G.G., 2001, School Participation in Rural India, Review of Development Economics 5(1): 1-24.

ERNWACA, 2002, Transnational view of Basic Education: Issues of Access, Quality and Community Participation in West and Central Africa, Educational Research Network for West and Central Africa (ERNWACA) (January).

Gertler, P. and Alderman, H. (1989), Family Resources and Gender Differences in Human Capital Investments, Economic Growth Center, Yale University (mimeo).

Gibson, J., 2001, Unobservable Family Effects and the Apparent External Benefits of Education, Economics of Education Review 20: 225-233.

Glaeser, E.L., Laibson, D. and Sacerdote, B., 2002, The Economic Approach to Social Capital, The Economic Journal 112 (November): F437-F458.

Glick, P. and Sahn, D.E., 2000, Schooling of Girls and Boys in a West African Country: The Effects of Parental Education, Income, and Household Structure, Economics of Education Review 19(1): 63-87.

Grootaert, C., 1999, Social Capital, Household Welfare, and Poverty in Indonesia, Local Level Institutions Working Paper No. 6, Washington, DC: World Bank.

Grootaert, C., Narayan, D., Nyhan Jones, V. and Woolcock, M., 2004, Measuring Social Capital: An Integrated Questionnaire, World Bank Working Paper No. 18.

Halpern, D., 1999, Social Capital: The New Golden Goose, Faculty of Social and Political Sciences, Cambridge University (unpublished review).

Handa, S. ,1996, The Determinants of Teenage Schooling in Jamaica: Rich vs. Poor, Females vs. Males, Journal of Development Studies 32: 554-580.

Hanifan, L.J., 1916, The Rural School Community Centre, Annals of the American Academy of Political and Social Sciences 67: 130-138.

Homans, G. ,1961, Social Behavior: Its Elementary Forms, New York: Harcourt, Brace and World.

Kingdon, G.G., 1998, Does the Labour Market Explain Lower female Schooling in India?, Journal of Development Studies 35(1), 10: 39-65. 
Knack, S., 2001, Trust, Associational life and Economic Performance, in Helliwell, J.F. (ed.), The Contribution of Human and Social Capital to Sustained Economic Growth and Well-being, International Symposium Report, Human Resources Development Canada and OECD.

Knack, S. and Keefer, P., 1997, Does social capital have an economic pay off? Acrosscountry investigation, Quarterly Journal of Economics 112: 1251-1288.

Koura, D., 2001, L’influence des facteurs familiaux, scolaires et individuels sur l'abandon scolaire des filles en milieu rural, de la région de Ségou (Mali), Thèse de Doctorat (Ph.D.), Université de Montréal, Spécialité Sciences de l'Éducation, http://www.bcltechnologies.com/allpdf/

La Porta, R., Lopez-De-Silanes, F., Andrei, S. and Vishny, R., 1999, The quality of governments, Journal of Law and Economics (January): 222-278.

Lloyd, C.B. and Blanc, A.K., 1996, Children's schooling in sub-Saharan Africa: The role of Fathers, Mothers, and Others, Population and Development Review 22(2): 265-298.

Loury, G., 1977, A Dynamic Theory of Racial Income Differences, in Wallace, P.A. and Le Mund, E. (eds), Women, Minorities, and Employment Discrimination. Lexington, MA: Lexington Books.

Maluccio, J., Haddad, L. and May, J., 2002, Social Capital and Household Welfare in South Africa, 1993-98, Journal of Development Studies 36(6).

Meier, A., 1999, Social Capital and School Achievement among Adolescents, CDE Working Paper No. 99-18, University of Wisconsin-Madison

Milligan, K., Moretti, E. and Oreopoulos, P., 2003, Does Education Improve Citizenship? Evidence from the US and the UK, NBER Working Paper No. 9584.

Narayan, Deepa, 1999), Complementarity and Substitution: The Role of Social Capital, Civic Engagement and Formal Institution in Poverty Reduction, Washington, DC (mimeo).

Narayan, D. and Pritchett, ??, 1999, Cents and Sociability: Household Income and Social Capital in Rural Tanzania, Economic Development and Change 47( 4).

N'jie, Makaireh, Loum, Abdoulie and Benet, Yves, 2002, Study of Parent-Teacher Associations at Lower Basic Schools in The Gambia, Department of State for Education and Action Aid, ERNWACA, Banjul, Gambia, 75pp.

OECD, 1998, Human Capital Investment, an International Comparison, Paris.

Olanrewaju, O., 2003, An empirical study of the gender gap in children schooling in Nigeria, African Journal of Economic Policy 10(1).

Putnam, R.D., 1993,. The Prosperous Community - Social Capital and Public Life, American Prospect 13: 35-42.

Putnam, R.D., 1995a, Bowling Alone: America’s Declining Social Capital, Journal of Democracy 6(1): 65-78.

Putnam, R.D., 1995b, Tuning in, Tuning Out: The Strange Disappearance of Social Capital in America, Political Science and Politics XXVIII: 664-683.

Putnam, R.D., 2000, Bowling Alone: The Collapse and Revival of American Community, New York: Simon \& Schuster. 
Sangare, S. and Diarra, I., 1997, Effet de la participation communautaires sur l'accès et la qualités de l'éducation de base: Le cas du Mali, ROCARE/Mali.

Seeley, J.R., Sim, A.R. and Loosley, E.W., 1956, Crestwood Heights: A Study of the Culture of Suburban Ife, New York: Basic Books.

Smith, M.H., Beaulieu, L.J. and Seraphine, A., 1995, Social Capital, Place of Residence and College Attendance, Rural Sociology 60(3): 363-381.

Tabi, A.J., 2010, Social Capital and Household Welfare in Cameroon: A Multidimensional Analysis” Revised Final Report, African Economic Research Consortium (AERC), Nairobi.

Tawah, R., 1998, Female Education in Cameroon, Bulletin No. 13 du Réseau OCISCA (Observatoire du Changement de l'innovation Sociale au Cameroun).

Teachman, J.D., Paasch, K. and Carver, K., 1996, Social Capital and Dropping Out of School Early, Journal of Marriage and the Family 58(9): 773-784.

UNICEF, Girls' Education in Cameroon: 2003 Cameroon Country Highlights, www.unicef.org/girlseducation/index.html

Woolcock, M., 2001, The Place of Social Capital in Understanding Social and Economic Outcomes, ISUMA Canadian Journal of Policy Research 2(1): 11-17.

Woolcock, M. and Narayan, D., 2000, Social Capital: Implications for Development Theory, Research and Policy, World Bank Research Observer 15(2).

World Bank, 1998, The Initiative on Defining, Monitoring and Measuring Social Capital: Overview and Program Description, Social Capital Initiative Working Paper No. 1, Washington, DC: World Bank.

Zhang, J. and Davies, J., 1995, Gender Bias, Investments in Children and Bequests, International Economic Review 36(3); 795-818. 